doi:10.29285/actapinteriana.2020.6.73

\title{
Assisi Szent Ferenc Eucharisztia-tisztelete
}

\author{
Berhidai Lajos Piusz OFM \\ Szécsényi Ferences Rendház, 3170 Szécsény, Haynald u. 9. \\ piuszofm@gmail.com
}

Berhidai L. P. (2020): Assisi Szent Ferenc Eucharisztia-tisztelete. La venerazione eucaristica di San Francesco d'Assisi. Acta Pintériana, 6: 73-87.

\begin{abstract}
La ricerca mira ad indagare l'importanza della relazione di San Francesco d'Assisi nella sua esperienza di fede con il sacramento dell'Eucaristia. Dopo una disamina dell'argomento nel contesto della storia della Chiesa trecentesca vengono analizzati, nel prosieguo dell'articolo le parti pertinenti degli scritti di San Francesco. Dalle analisi condotte emerge una devozione eucaristica con le seguenti particolarità: il comportamento interno del fedele e l'unione mistica per mezzo del Sacramento, una considerazione d'insieme dei misteri dell'Incarnazione, della Salvezza e dell'Eucaristia; una particolare cura della liturgia; e una promozione della devozione eucaristica. L'ultima parte della ricerca delucida, in un contesto più ampio, la relazione tra l'Eucaristia e la vita da frate minore.
\end{abstract}

\section{Bevezetés}

A keresztény hit legjelentősebb állítása, hogy az az ember, akit Názáreti Jézusként tart számon a történelem, meghalt és feltámadt, és személyében, mint második isteni személyben, az egyetlen Isten nyilatkoztatta ki magát. Jézus feltámadott jelenléte ezért minden krisztushívő számára szüntelen és kimeríthetetlen misztérium. A szentek éppen azért válnak példaképpé a hívő emberek számára, mert életükkel, magatartásukkal, erényességükkel ennek a feltámadott létnek a tanúi. Ennek a hívő magatartásnak és szemléletmódnak egy kiemelkedő eleme az eucharisztikus jelenlét belátása: az utolsó vacsora során Jézus a kenyérben és borban önmagát nyújtja azzal a rendelkezéssel, hogy benne hívő tanítványai az ő emlékezetére cselekedjék majd ugyanezt újra és újra. Az Evangéliumban felkínált életforma az önátadás életformája, s ennek forrása a tanítványi közösség számára az eucharisztia, mint a feltámadást ünneplő Egyház megjelenítő emlékezése, és az Eucharisztia, mint az a szent táplálék, amit magához véve a hívő megéli a feltámadt Jézus Krisztussal való egységét. ${ }^{1}$

Assisi Szent Ferenc írásaiban feltünő módon jelen van ez a hit (kis- és nagybetüs értelemben egyaránt). Ez annál szembetűnőbb, minél kevésbé jelenik meg ez a téma a különféle ábrázolásokban, valamint a rá hivatkozó közbeszédben, ahol gyakran meg kell elégednünk az olyan sablonos elemekkel és sztereotípiákkal, mint pl. világias életet élő fiatal, aki megtér; az intézményes egyházi kereteket feszegető szabad szellem; az első környezetvédő, illetve az állatok védőszentje. Ezek valóban kiemelik

1 Az eucharisztia és az egyház szavak kis vagy nagy kezdőbetűvel való írásában azt az elvet követem, amelyet Paul McPartlan is megfogalmaz: „Az 'egyház' szót általában kisbetüvel irjuk, amikor világosan helyi egyházról (részegyház, egyházmegye) van szó. A nagybetü ezeken az oldalakon hangsúlyosan a világegyház misztikus valóságára utal. Hasonlóan, az 'eucharisztia' szót kisbetüvel írjuk, amikor az eucharisztia egész liturgikus ünneplésére vonatkozik, és nagybetüvel, amikor szoros értelemben a Szent Testet és Vért jelzi" (MCPARTLAN 2015, p. 16). 
Ferenc életének egy-egy mozzanatát, de egy pusztán horizontális (hit nélküli) síkon szemlélve elveszítik eredeti értelmüket, és csak az éppen aktuális modern kulturális divat, ideológia vagy mozgalom kisajátításának eszközeivé válnak. Ha nemcsak magunkat akarjuk viszontlátni vagy -hallani erről az assisi emberről alkotott képünkben, akkor rá kell kérdeznünk: Vajon milyen hit és istenkeresés, milyen vallásos tapasztalat és megismerés képezi a hátterét vagy mozgatórugóját egy olyan döntésnek, hogy odahagyja induló karrierjét, és kivonuljon Assisiből, hogy tehetős városi polgár létére a városon kívüli életformába kezdjen leprásokat ápolva és elhanyagolt templomokat rendbe téve?

Ha Ferencet a saját írásain keresztül közelítjük meg, egy mélyen hívő keresztény gondolkodásmód tárul fel előttünk, amely a keresztény hit igazságairól, mint saját belátásairól tanúskodik, s amely eredője lesz egy új szerzetesközösségnek, de egy egész lelkiségi mozgalomnak (családnak) is mind a mai napig. Ennek a mély - egyszerre katolikus és személyes - hittapasztalatnak hangsúlyos eleme az Eucharisztiatisztelet. $^{2}$

\section{Az Eucharisztia a 13. századi Európában}

A téma történeti hátterét megvilágítja, ha felidézzük egyrészt a korabeli eretnekmozgalmakat, valamint az azokra is válaszoló IV. Lateráni Zsinatot (1215. november), amelyet III. Ince pápa (†1216) hívott össze és vezetett, és amely a középkor legfontosabb egyetemes zsinata volt (vö. PIERRARD 1994, pp. 107-108). Nem bizonyított, hogy maga Ferenc jelen volt rajta, de jelentőségét mutatja a kb. 1200 küldött és résztvevő - keleti és nyugati püspökök, szerzetesi elöljárók, királyok és fejedelmek -, és a három ülés alatt megfogalmazott 70 (vagy 71) kánon vagy konstitúció (lásd CONCILIUM LATERANENSE IV 1215). ${ }^{3}$

E rendelkezések élén egy olyan hitvallás áll, amely az albiak és katharok felfogására reagálva többek között az átlényegülés tanát is kimondja (1. kánon). A zsinat továbbá elöírja az Oltáriszentség gondos örzését (20. kánon). A hívek szentségi életének megújítása érdekében elrendeli az évenként legalább egyszeri gyónást és húsvéti szentáldozást (21. kánon). Ezeken túl a zsinati atyák felléptek az eretnekmozgalmak ellen, rendelkeztek a mohamedánok és zsidók keresztényektől való fokozottabb elkülönítéséről, az inkvizíciókról, valamint az új keresztes hadjárat (1217) indításáról is. Ha Szent Ferenc lelkiségének hátterében olvassuk a zsinat döntéseit, akkor külön említést érdemel az a rendelkezés, amely a hívő élet tudatosabbá válását célozta az anyanyelvű prédikációk előírásával (10. kánon).

Az eucharisztikus jelenlét tudatosítására irányuló zsinati megfogalmazások hátterében nyilván e tudatosság hiánya állt ennek gyakorlati vonatkozásaival együtt. Koszos, elhanyagolt templomok és tabernákulumok, néhol romlott Szentostya. Jelzésértékü, hogy III. Ince pápa maga is írt egy külön értekezést, amelyben a szentmise rendjének bemutatása után részletesen magyarázza a liturgikus cselekmények értelmét, és kitér olyan részletkérdésre, hogy vajon mit kell gondolnunk akkor, amikor a szentséget megrágja az egér, vagy tüz égeti meg. (A válasz szerint ilyenkor a szentségi jelenlét addig őrződik meg, amíg a színek, azaz a kenyér vagy a bor mivolta megmarad.) ${ }^{4}$ A korabeli állapotokról tanúskodik Ferenc megtérésének egyik fontos mozzanata is. Amint ráeszmél az isteni jelenlétre a templomokban, legfőbb törekvése azok kitakarítása, sőt a papok erre való tanítása:

„,időnként bejárta az Assisi környékbeli falvakat és templomokat [...], és magával vitt egy seprüt, hogy a templomokat kitakaritsa. Ha ugyanis bement egy

2 Ezt a véleményt támasztja alá Cesare Vaiani, amikor a Szent Ferenc lelkiségét alkotó föbb témák között beszél egyrészt a „hit és látás”, valamint az „ige és Eucharisztia” összefüggéséről (vö. VAIANI 2015, pp. 435-475).

Magyarul olvasható részletek: FILA \& JUG 1997, pp. 226-233.

4 Lásd INNOCENTIUS III (PL 217,763-915). Az említett téma a negyedik könyv 11. fejezetében kerül kifejtésre (vö. PL 217,863). 
templomba, nagyon fájlalta, ha azt nem találta tisztán. Ezért mindig, miután a népnek prédikált, a beszéd végeztével összehivta az ott lévö papokat egy félreesö helyre, hogy a világiak ne hallják, és prédikált nekik a lelkek üdvéröl, különösen pedig arról, hogy viseljenek gondot és forditsanak figyelmet a templomok, az oltárok és minden olyan dolog tisztán tartására, ami az isteni titkok ünneplésére szolgál." (PL 18)

III. Ince pápa Eucharisztia-hitet erösítő törekvései utódánál, III. Honoriusznál (†1227) is megjelennek a spanyol püspököknek küldött Sane cum olim bullában (1219), melynek megfogalmazása Ferenc írásaiban is visszhangzik:

\section{„A papok az Eucharisztiát mindig egy különálló, tiszta és tisztelettel felékesitett helyen tartva örizzék, hivö áhitattal. "5}

Az Eucharisztiával kapcsolatos visszaélések, tudatlanság (vagy nem eléggé tudatos vallásosság) és a különféle eretnekmozgalmak szentségekre vonatkozó kijelentései egymást is erősítve kerültek szembe azzal a hittel, amelyet a IV. Lateráni Zsinat a megelőző évszázadok hagyományára, teológiájára és liturgikus gyakorlatára támaszkodva kimondott. A középkor során olyan szegénységi mozgalmak jelennek meg és terjednek el rövid idő alatt Európában, amelyek elégedetlenségüknek adnak hangot a feudális rendszerbe teljesen beágyazódó és földi javakat halmozó Egyházzal szemben (vö. PIERRARD 1994, pp. 91-95). Eszményük az apostolok evangéliumi szegénysége és az ősegyház vagyonközössége. A 12. század elején ilyen volt Bresciai Arnold mozgalma, majd a szintén lombardiai eredetü humiliánusoké, akiknek nagy része azonban egy évszázados történet során visszatért az Egyházba. Önmegtartóztató, szigorú élet és az ősegyház eszményítése jellemezte őket, amelyhez antiklerikalizmus társult, számüzve a szentmisét és a szentségeket. A lyoni Pierre Valdontól eredő valdiak (vagy valdensek) hasonló eszméket vallottak, már 1184-ben kiközösítés sújtotta őket, majd végül Piemontban telepedtek le a 13. században. Szintén jelentős volt a katharok vagy albigensek csoportosulása, akiknek gyökerei a 10. századi bizánci birodalom bogumiljeire nyúlnak vissza, s akiknek a tanítása Bosznián, Albánián és Lombardián át jutott el és erősödött meg Dél-Franciaországban. ${ }^{6}$ Fő vonásuk - a manicheizmust újraélesztő dualista istenfelfogáson túl - a „konstantini adomány” óta hiteltelen Egyházzal való szembenállás volt, ám ez együtt járt az adott feudális társadalom és hierarchia elleni fellépéssel. A szentségekről, és különösen az Eucharisztiáról vallott felfogás tehát messzemenően beágyazódott egy társadalmi és politikai konfliktusba is, illetve szorosan összefonódott azzal.

Az eretnekek ellen vezetett keresztes hadjárat és az inkvizíció intézménye mellett a 12-13. század folyamán békés válaszok is születtek az Egyházban az ugyanazon eretnekek által kimondott problémákra. Ilyen válaszként is felfogható a monasztikus hagyományt reformáló ciszterci megújulás Szent Bernát vezetésével, majd a prédikáció szolgálatát vállaló és közben az evangéliumi szegénység eszményét felmutató koldulórendek Szent Domonkossal és Szent Ferenccel.

Mindezzel együtt járt két fontos változás a nyugati kereszténységet jellemző gondolkodásban. Egyrészt az Evangélium értelmezése és hirdetése ezentúl még kevésbé lehetett csak a klerikusok kiváltsága, hiszen a laikusok tömegei is igényt tartottak rá. Másrészt az Evangélium és az evangéliumi szegénység középpontba állitásával a második isteni személy emberi mivolta, Jézus embersége sokkal inkább felértékelődött a korábbi teológiai elképzelésekhez képest. Többek között ez a szemlélet erősítette a Szentföld felszabadítására való mozgósítást, hiszen Jeruzsálemet a zarándokok érdekében

„, Quatenus a sacerdotibus Eucharistia in loco singuli, mundo etiam et signato semper honorifice collocata, devote ac fideliter conservetur." (vö. Sacrorum conciliorum nova et amplissima collectio 1778, 754 CD. Idézi: MARANESI, 2009, p. 178)

6 Jelenlétük leginkább Albi városa környékén erősödött meg, innen származott az albigens elnevezés (vö. PIERRARD 1994, pp. 92). 
kellett felszabadítani, akik üdvösségük eszközének tartották, ha a Megváltó földi útjának nyomait felkereshetik.

Ebben az egyház- és lelkiségtörténeti összefüggésben tekintünk rá Assisi Szent Ferenc Eucharisztiatiszteletére.

\section{Az Eucharisztia Szent Ferenc írásaiban}

A ránk maradt nem túl terjedelmes szövegkorpusz müfaji tekintetben - és nem szigorúan elkülönítve egymástól - imádságokat, leveleket és életszabályokat tartalmaz. ${ }^{7}$ Ezekben körülbelül tízszer olvasunk kifejezetten az Eucharisztiáról, különböző mélységben és hangsúlyokkal. Ezeken kívül még kétszer idézi föl Ferenc a lábmosás metaforáját a testvérek egymással való kapcsolatát leírva, s ez szintén fontos, „eucharisztikus” utalás a János-evangélium és Ferenc írásainak összefüggésében. ${ }^{8}$ Ez a gyakoriság már pusztán mennyiségi szempontból is jelentős témának mutatja az Eucharisztia-tiszteletet Szent Ferenc lelkiségén belül.

Mivel Ferenc nem skolasztikus teológusként értekezik, ezért az egyes idézetekben összefonódik az Eucharisztia teológiája a hozzá kapcsolódó hívő gyakorlattal, valamint a keresztény hit más misztériumaival. Vegyük sorra ezeket a szövegeket a bennük megjelenő főbb témák mentén!

\section{Imádás és kontempláció (Imádunk téged; A Miatyánk kifejtése)}

Assisi Szent Ferenc írásainak többsége évekkel a megtérése után íródott. Imádságainak jó része is egy olyan emberre utal, aki a belső úton már elörehaladt, tapasztalatokat szerzett, és így integrált és koherens hitre jutott: az általános érvényü hitigazságok személyes belátásaiként jelennek meg, különböző megnyilatkozásai szerves egységet alkotnak. Mégis a mélyebb hitre jutás kezdeti korszakára tehető az Ima a Keresztrefeszitett elött (Fölséges és dicsőséges...), valamint saját visszaemlékezése szerint az Imádunk téged... (Adoramus te...) kezdetü fohász (Végr 5). Az istenkeresés helye és közege Ferenc számára a természet vagy a templom volt, ahol hosszan időzött egyedül. Ugyanakkor a templom a liturgia helye is volt, amely a megtérő istenkapcsolatának egyik fö forrása lett. A Keresztrefeszített előtti imát a hagyomány a San Damiano-templomban történt élményhez kapcsolja, amikor Ferenc a festett keresztről hallja Jézus szavát (CÉ2 10). A templomban való csendes imádkozás fontos része lett új életének: ,,igen-igen szívesen idöztünk templomokban” - írja Végrendeletében (Végr 18). Az ilyen időzések alkalmával a kereszt szemlélése mellett kötött szövegü imák segíthették az egyéni elmélkedést, elsősorban a Miatyánk és a liturgia szavai. E két tényező - a kereszt szemlélése és a liturgia - egyszerre lesz forrása az Imádunk téged kezdetü fohásznak, amely eredetileg egy, a Szent Kereszt ünnepén felhangzó antifóna. Ahogy a kereszt a legfontosabb emlékeztető volt Ferenc számára, vagyis az a szimbólum, amely által bárhol és bármikor Krisztus jelenlétébe tudott helyezkedni, úgy az Úr imádsága a legfontosabb szóbeli ima. Korai életrajzi források is megerősítik, hogy a Végrendeletben fennmaradt Adoramus te... az első testvéri közösség gyakori imádságává vált (CÉ 1,45; PN 19). A Miatyánk szintén fontos szerepet töltött be Ferenc és az első testvérek imaéletében, főképp ha meggondoljuk, hogy a

7 Lásd Assisi Szent Ferenc (2018): Assisi Szent Ferenc irásai (Ferences Források Magyarul 3.), Magyarok Nagyasszonya Ferences Rendtartomány, Budapest. Az egyes szövegeket e kiadás szerint idézem, és az e kötetben alkalmazott rövidítésekkel jelölöm. (B. P.)

8 E szöveghelyek Szent Ferenc írásaiban: MKif 6; LKler; LÖr; LNVez 6; 2LHív 6-14, 22-24, 33-35, 63; LRend; Int 1,8-22; 4; 26; RnB 6,4; Végr 5,10-11. 
kezdeti időben még nem tudtak zsolozsmázni, így csak alapimádságokra szorítkozhattak, illetve arra, amit a szentmisén hallottak. ${ }^{9}$

Ezek fényében válik jelentőssé, hogy Ferenc úgy bővíti ki ezt a két legfontosabb - napi - imádságát, hogy megvallja bennük az eucharisztikus jelenléthez való ragaszkodását:

„Imádunk téged, Úr Jézus Krisztus,

minden templomodban az egész világon,

és áldunk téged, mert szent kereszted által megváltottad a világot." (Végr 5) ${ }^{10}$

Jézus Krisztus templomi jelenléte az Eucharisztia mellett Isten igéjéhez és a templomban összegyült hívő közösséghez, sőt - ahogy A hivőökhöz irt levélben látni fogjuk - az egyes krisztushívőhöz is köthetö. Szembetűnő azonban, ahogy a rövid imádságban egymás mellé kerül az Eucharisztia és a megváltás misztériuma. Ha az imához tartozó helyzetet is felidézzük, ti. hogy Ferenc és társai ezt mindig egy templomban vagy egy út menti kereszt előtt mondták leborulva, akkor világossá válik, hogy a szövegben egyértelműen azt az Urat szólítják meg, aki a Golgotán Poncius Pilátus idején kereszthalált halt, de ott és a világ összes templomában jelenvalóvá válik, és mindig aktuálisan jelen van.

A Miatyánk kifejtése valójában nem kifejtés vagy magyarázat, hanem egy kibővített imádság, ahol minden sor az egyéni elmélkedés révén folytatódik. A középső kéréshez a következő betoldás kapcsolódik:

\section{„Mindennapi kenyerünket, a te szeretett Fiadat, a mi Urunk Jézus Krisztust, add meg nekünk ma: \\ annak a szerelemnek az emlékezetére, megértésére és tiszteletére, mellyel irántunk viseltetett, és azokéra, amiket értünk mondott, tett és szenvedett."}

A mindennapi kenyérnek Jézus Krisztussal való azonosítása a patrisztikus írásokban is jelen van, és végigkövethető az Egyház hagyományában. ${ }^{11}$ A Ferencnél ezzel együtt megjelenő téma - vagy inkább látásmód - az, ahogy ő az Isten irántunk való szeretetét szemléli Jézus Krisztusban. Ennek a „szerelemnek az emlékezete, megértése és tisztelete” nem más, mint a szentmise, ahol a hívő (közösség) Jézus értünk kimondott szavait, értünk véghezvitt cselekedeteit és keresztáldozatát szemléli és ünnepli. Ahogy a további idézetek is megvilágítják, Ferenc istenkeresésének meghatározó eleme volt az Eucharisztia misztériumára való rácsodálkozás, s ennek előfeltétele vagy közege a liturgikus környezet volt. A liturgia rendszeres megélése egyéni kontemplációra vezette, s így az Eucharisztia-tiszteletét meghatározó két magatartás az imádás és a szemlélés lett: észrevenni, hittel látni azt, Aki feltámadása által örökké jelen van, és a liturgiában szemlélni és imádni Öt.

\section{A megtestesülés alázata az eucharisztiában (Int 1)}

A fenti gondolat - hittel látni - nyer bővebb kifejtést az első intelemben. Az Intelmek egy 28 rövid lelki tanításból álló szövegfüzér, amely stílusában leginkább a sivatagi atyák apoftegmáival rokonítható (vö. BRUNETTE 2016, p. 13), jóllehet létrejöttük a testvérek nagykáptalanjaihoz köthető. Az ilyen összejövetelek alkalmával a testvérek saját hivatásuk megélésének különböző problémás helyzeteit vitatták meg, és Ferenc, aki haláláig a közösség karizmatikus vezetője maradt, az ilyenkor felmerülő

9 Vö. RnB 22,28, valamint RnB 3 és RB 3; 2LHív 21; továbbá az Úr imája Ferenc személyes történetében: 3Társ 20; CÉ2 12. Az Úr misztériumainak zsolozsmájához tartozó meghagyásaiban ugyancsak arról olvasunk, hogy a Ferenc által szerkesztett „,kis zsolozsmának” szintén része volt a Miatyánk mondása (vö. DMI és Zs, rubrika).

10 Az eredeti antifóna dölten szedve a szövegben.

11 Vö. Augustinus: Sermo 57, 7,7 (PL 38,389-390); P. Chrysologus: Sermo 67, 7 (PL 52,392b); CypriAnus: De Oratione Dominica, 18 (PL 4,531). 
kérdésekre reagált. Válaszai valódi lelki atyai tanácsok voltak, amelyek lejegyezve általános érvényü tanításokként maradtak az utókorra (vö. CAROLI 2004, pp. 57-58; FRANCESCO, D’ASSISI 2009, p. 346).

Az Intelmek első darabja formailag és tartalmilag is eltér a következő 27-töl. Egyrészt ez a leghosszabb, másrészt tartalmában mintha teológiai és lelkiségi alapját adná az összes többinek. Az Intelmek jó része egy-egy hívő vagy szerzetesi élethelyzettel kapcsolatban írja le a helyes, illetve helytelen hozzáállást, mindvégig szem előtt tartva, hogy milyen az igazi kisebb testvér. (E logika alól csak a 27. kivétel, amelyben erények és vétkek páros szembeállítása képez egy már költői szöveget.) Az első tanítás azonban - ha rövid tartalmi összefoglalását akarjuk adni - nem az ember, hanem Isten alázatáról szól, valójában mély teológia, amelyben összekapcsolódik a megtestesülés és az Eucharisztia misztériuma, s amely jól szemlélteti Ferenc szentháromságos krisztusközpontúságát (vö. VAIANI 2013, pp. 20-25).

A felvezetést Jézusnak az utolsó vacsorán elhangzó szavai adják Szent János evangéliuma szerint, s a kiindulópont az elérhetetlen és láthatatlan Atya elérése, látása:

„Uram, mutasd meg nekünk az Atyát [...]. Fülöp, aki engem lát, Atyámat is látja."

$(\mathrm{Jn} 14,9)$

Ferenc hittapasztalatának mozgatórugója a látás: egzisztenciális szükségletként tör fel belőle, hogy látni és hinni akar (vö. VAIANI, C. (2015, pp. 453-457).

„Az Atya megközelithetetlen fényességben lakozik, és lélek az Isten, és Istent soha senki sem látta. Ezért csak lélekben látható” (Int 1,5)

- folytatja a Biblia szavaival átszőve és kifejezve belső tapasztalatát (vö. 1Tim 6,16; Jn 4,24; Jn 1,18). Jézus Krisztus jelenvalósága éppen ezért válik fontossá, nélkülözhetetlenné az Evangéliumban és az Eucharisztiában, mert ezekben tapasztalható, érzékszerveinkkel befogadható a jelenlét. Szavait halljuk, a kenyérben és borban látjuk, érintjük, magunkhoz vesszük. Az elérhetetlen elérhetővé teszi magát. A „látni és hinni” tapasztalatának ez a vágya végighúzódik Ferenc életútján: tapasztalni akarja a kolduslétet, ezért ruhát cserél Rómában a koldussal, látni akarja a betlehemi pillanatot, ezért Greccióban barlangistállóban rendez éjféli misét karácsonykor, halála elött csaknem teljesen vakon énekli Naptestvér énekét, aki szép és ragyogó világosságával a Legfölségesebb látható jele. A hitben való látás és érzékelés lesz így számára az üdvösség útja.

Az intelem párhuzamba állítja a földi Jézus hittel való látását és az Eucharisztia hittel való szemlélését:

„Mindazok tehát, akik az Úr Jézust az emberség szerint látták, de nem látták és nem hitték a lélek és az istenség szerint, hogy ö az Isten valóságos Fia, kárhozottak. Éppen így mindazok, akik látják ugyan a szentséget, mely az Úr igéi által megszentelödik az oltáron a pap kezei között a kenyér és a bor alakjában, de nem látják s nem hiszik a lélek és az istenség szerint, hogy az valóságosan a mi Urunk Jézus Krisztus legszentebb teste és vére, kárhozottak.” (Int 1,8-9)

Feltünő, hogy Szent Ferenc soha nem beszélt kifejezetten a szentségi élet gyakorlatát megkérdőjelező eretnekek ellen, holott nehéz elképzelni, hogy ne találkozott volna velük vagy eszméikkel. A Megerösitett regula 12. fejezetében azokról a testvérekről van szó, „akik a szaracénok vagy más hitetlenek közé mennek”. Itt a címben szereplő „más hitetlenek” (alios infideles) kifejezés ugyan megengedi, hogy azokra a vallási-etnikai csoportokra is gondoljunk, amelyek a római egyházon kívül álltak (zsidók, eretnekek, keleti keresztények), s a korabeli szóhasználat szerint hitetleneknek hívták őket a keresztény nyugaton (vö. FRANCESCO, D’ASSISI 2012, p. 589). Itt azonban csak a kisebb testvérek missziós magatartásáról és misszióba küldésének módjáról olvasunk, többek között azt, hogy mint kisebbek és alárendeltek legyenek jelen, kerülve a vitát és a veszekedést (vö. RnB 16, RB 12,1-2). Ferenc 
az eucharisztikus jelenlétbe vetett hitét elsősorban hívő, „katolikus” hívőkkel osztja meg, akár szerzetesek, akár világiak. Éppen azt fedezi fel újra, ami az egyébként vallásos környezetében feledésbe merült, középpontba állítja azt, amit a korabeli hitélet perifériára szorított.

Az első intelem tovább erősíti a szentmise és a megtestesülés egymás mellé állítását, $\mathrm{s}$ eszerint a hitben való látás kezdete a szentmise:

„Miért nem ismeritek fel az igazságot, és miért nem hisztek Isten Fiában? Íme,
mindennap megalázza magát, mint akkor, amikor a királyi trónról jött a Szüz
méhébe; mindennap ö maga jön hozzánk alázatos külsőben; mindennap leszáll
az Atya kebléröl az oltárra a pap kezében.” (Int 1,15-18)

Amint a megtestesülésben szemlélhetjük Isten alázatát, úgy a mindennapi liturgiában is. Ezzel persze a karácsonyi misztérium is egy örök távlattal együtt ünnepelhető, hiszen az eucharisztiában való megújulása és ismétlődése által a feltámadt Úr állandó és örök jelenlétére nyit meg. Ezért fejeződik be az intelem úgy, hogy az eucharisztikus jelenléthez kapcsolja a Máté-evangélium zárószavait:

„És így van az Úr mindenkoron hiveivel, amint ö maga mondotta: 'Íme, én veletek vagyok egészen a világ végezetéig'." (Mt 28,20)

Az ebben a szövegben megjelenő misztérium, mely szerint az Atya elküldte és nap nap után küldi a Fiút nekünk, számos alkalommal előfordul máshol is az Írásokban. Amikor a már zsolozsmázni megtanult Ferenc saját maga szerkeszt zsoltárokat - az eredeti sorokat mintegy magába emelve és szabadon újraírva -, szembetűnő, hogy a bibliai szavakat saját szavaival vagy a liturgiából vett kifejezésekkel egészíti ki. Az Úr misztériumainak zsolozsmájában az egyik ilyen ismétlődő fordulat a Fiú hozzánk és értünk való küldése az Atya által (Zs 7,3; 11,6; 15,3). Ferenc ezt a többféle módon megvalósuló igazságot szemléli az eucharisztiában is.

\section{A szentmise (Az egész rendhez irt levél)}

Ferenc ránk maradt levelei közül csak a magánszemélyeknek küldöttek nem szólnak az Eucharisztiáról. ${ }^{12}$ E témában a legbővebben rendi testvéreinek címzett levelében ír. A Perugiai legenda 80. fejezete beszámol arról, hogy az itt szereplő gondolatokat a Regulába is be akarta vetetni, de az ekkor már nem volt lehetséges, hiszen a pápai megerősítés után már nem lehetett hozzátenni (vö. PL 80). ${ }^{13} \mathrm{Az}$ itt olvasható meglátások és kérések tehát 1224-re tehetők, Ferenc halála elött két évvel.

A fennkölt bevezetés (1-11) után a levélnek mintegy felét kitevő eucharisztikus gondolatok következnek az Úr teste és vére iránti tiszteletről (12-13), a szentmise bemutatásáról (14-29) - kifejtve a papok méltóságát -, a közös misehallgatásról (30-33) és a liturgikus eszközök és írások körültekintő örzéséröl (34-37). A továbbiakban Ferenc testvér gyónása következik, valamint buzdítás a regula engedelmes megtartására, különösképpen a zsolozsma imádkozására (38-49).

A mi szempontunkból fontos részt a 11. vers vezeti be:

„Mint fiaknak, kínálja magát nektek az Úristen.”

Eszerint az Eucharisztia misztériumában Isten önajándékozása szemlélhetö. Ferenc minden testvért felszólít a legszentebb Test és Vér tiszteletére, „melyben minden, ami a mennyben és a földön van, megbékélt és kiengesztelödött a mindenható Istennel" (LRend 13). Ez az egyetemes kiengesztelődés, amely Isten megelőző szeretete révén válhatott valóra, indokolja a legnagyobb tiszteletet és körültekintő figyelmet minden hívő részéről, de különösen a szentmisét - amely „, a mi Urunk Jézus Krisztus legszentebb testének és vérének valódi áldozata" (LRend 14) - bemutató papoktól. A levél elragadtatott

12 Vagyis a 10-ből csak három.

13 Az egész rendhez írt levél datálásával kapcsolatban lásd FRANCESCO, D’ASSISI 2009, p. 204. 
hangon szól a misztériumról, ugyanakkor kemény szavakkal és határozott felszólítással fordul a papokhoz:

„,megveti, megszentségteleníti és lábbal tiporja az ember Isten Bárányát, amikor, miként az Apostol mondja, nem különbözteti meg, és nem választja külön Krisztus szent kenyerét egyéb eledelektöl vagy tevékenységektöl." (LRend 19)

Amikor Ferenc pap rendtársait kérleli, hogy összeszedetten, tisztán mutassák be a szentmisét, szavai egybevágnak a IV. Lateráni Zsinatnak a klerikusok életmódját és szolgálatát reformálni akaró rendelkezéseivel. A levél kifejezése: ,puri pure faciant cum reverentia [...] sancta intentione et munda”, azaz amikor misét celebrálnak, ,,tiszták legyenek, és tisztán, tisztelettel mutassák be [...] szent és feddhetetlen szándékkal”; a zsinat 14. kánonja pedig így fogalmaz: „puro corde ac mundo corpore valeant ministrare”, azaz a klerikusok „tiszta szívvel és tiszta testtel szolgáljanak” (LRend 14; Constitutiones Concilii Lateranensis 14).

Még nyomatékosabbá válik a buzdítás, amikor a szentmise titkát a Mária-kultusz, valamint - a keresztes hadjáratok korában - a Szent Sír tisztelete elé helyezi:

„Halljátok testvéreim! Ha a Boldogságos Szüzet méltán tisztelettel övezzük, mivel öt legszentebb méhében hordozta; ha a Keresztelö boldogan beléremegett, és nem merte megérinteni Isten szent fejét; ha külön tiszteletben részesitjük a sirt, amelyben egy ideig nyugodott; hát akkor milyen szentnek, igaznak és méltónak kell lennie annak, aki már nem a halandót, hanem az örökké élöt és megdicsöültet, kibe az angyalok bepillantani vágynak (vö. 1Pét 1,12), kezével érinti, szivével és ajkával magához veszi és vételre nyújtja másoknak?" (LRend 21-22)

A klerikusok méltósága az Eucharisztiában önmagát ajándékozó Isten méltóságából fakad. Ezért fordul - akár büneik ismeretében is - különös tisztelettel Ferenc a klerikusokhoz, ahogy erröl több írásában tanúságot tesz. ${ }^{14} \mathrm{E}$ tisztelet okát is megfogalmazza Végrendeletében:

„És ezt azért teszem, mert Isten legfölségesebb Fiából ezen a világon testileg semmi mást nem látok, mint legszentebb testét és legszentebb vérét, s ezeket ök veszik magukhoz, és egyedül ök szolgáltatják ki másoknak." (Végr 10)

A papi méltóságról való eszmélődés megrendülten tér vissza Isten méltóságának és alázatának szemlélésébe:

„Ó, fölséges alázatosság! Ó, alázatos fölség, hogy a mindenség Ura, Isten és az Isten Fia így megalázza magát, hogy a mi üdvösségünkért a kenyér szerény színe alá rejtezik!" (LRend 27)

Ferenc számára az Eucharisztia-tan nem pusztán racionális okfejtés, értelemkeresés és meghatározás, hanem az egész embert átjáró belátás, ami egy sajátos belső magatartásra is ösztökél. Ha Isten ilyen alázattal ajándékozza önmagát, akkor a hozzá térö ember sem maradhat meg magának, hanem az önátadás útját kell járnia:

„Semmit se tartsatok tehát vissza magatokból magatoknak, hogy egészen visszafogadjon benneteket az, aki egészen odaadja önmagát nektek. ”(LRend 29)

A feltámadott jelenlét mindenkit képes betölteni fogyatkozás nélkül, ezért Ferenc a napi egy közös mise hallgatására szólítja fel testvéreit. Az alábbi szavakba talán anakronisztikus volna belelátni a koncelebrálás mai katolikus gyakorlatát (ti. hogy több pap együtt misézik). Mégis figyelemreméltó hozzáállás ez a 13. században, különösen a szentmise történetének további alakulása szempontjából. Egyrészt pont az Eucharisztia-tisztelet középkori megerősödése támogatta, hogy a koncelebráció egyre

14 Vö. Végr 6-10 és 13 (ahol külön kitér a teológusok megbecsülésére); Int 26. 
inkább helyet adott a magánmiséknek, másrészt a Ferenc által kért közös misehallgatás gyakorlata meghaladja a későbbi korokra jellemző halmozását a magánmiséknek (vö. JUNGMANN 1977, pp. 217 219; KOVÁCs 2014). Az Eucharisztia lényegét szem előtt tartva fogalmazódik meg, hogy a pap testvérek

„,naponként csak egy misét mondjanak. Ha pedig több pap van azon a helyen, az egyik szeretetböl elégedjék meg a másik miséjének hallgatásával; mert a jelenlevöket és a távollevöket is, ha méltók rá, betölti az Úr Jézus Krisztus. Ö, bár látszatra több helyütt van, mégis osztatlan marad, és nem ismer semmi fogyatkozást, hanem egyként munkálkodik mindenütt, amint neki tetszik, az Úristennel, az Atyával és a Vigasztaló Szentlélekkel együtt mindörökkön örökké. Ámen" (LRend 30-33).

Az eucharisztikus jelenlét belátásából következik az a fokozott figyelem, amely mindenre kiterjed, ami a szent áldozatot körülveszi: liturgikus eszközök és könyvek, különös tekintettel „Isten írott igéire” (LRend 35). Ez utóbbiak alatt nemcsak a liturgia során használt könyvekre kell gondolnunk, hanem azokra a táblákra is, amelyekről az oltáron elhelyezve az átváltoztatás szavai voltak olvashatók.

„Mert sok dolog szentté lesz Isten igéi által, és az Oltáriszentség is Krisztus igéinek erejével jön létre." (LRend 37)

Az itt megfogalmazott törekvés visszhangzik a Végrendeletben is (vö. Végr 11-12). A mindennapi liturgikus gyakorlat felidézésekor Ferenc egy ponton saját magára is utal a szövegben, mint aki diakónusként maga is a klerikusok felelösségét viseli: ,,nekünk, akik különösképpen az isteni szolgálatra vagyunk rendelve" (LRend 34).

\section{Misztikus egység (Levél a hivoókhöz)}

A két változatban fennmaradt levél nagyszerü újdonsága, hogy benne Ferenc minden krisztushívőhöz szól. Ez az egyetemes küldetéstudat abból a meggyőződéséből fakad, hogy a Szentháromságos Isten minden hívő számára az önmagával való egységet nyújtja. A hívő, aki (1) az isten- és emberszeretet szerint éli életét, (2) a folyamatos megtérés útját járva bünbánatot tart, valamint (3) a szentségekből él: arra hivatott, hogy bensőjében a Szentháromság lakozzék.

„Mindazok, akik teljes szívvel, teljes lélekkel és elmével, minden erövel szeretik az Urat, és úgy szeretik felebarátjukat, mint önmagukat, és gyülölik testüket vétkeikkel és büneikkel együtt, és magukhoz veszik a mi Urunk Jézus Krisztus testét és vérét, és a bünbánat méltó gyümölcseit termik: Ó, mily boldogok és áldottak azok a férfiak és nök, amíg így cselekednek, és ezekben kitartanak, mert megnyugszik rajtuk az Úr Lelke, s lakóhelyet és szállást készít náluk magának; és fiai ök a mennyei Atyának, akinek müveit cselekszik, és jegyesei, testvérei és anyja a mi Urunk Jézus Krisztusnak." (1LHív 1-7) ${ }^{15}$

Az Istennel való egységnek ez a minden hívő számára történő bemutatása és felkínálása különösen nagy jelentőséggel bír abban a korban, amikor a tökéletes istenkapcsolat megvalósulását szinte kizárólag a világból kivonult, szerzetesi életformában tudták elképzelni. ${ }^{16}$ Ferenc valójában az Egyházban való

15 A hosszabb változatban: 2LHív 48-50.

16 Ezt az ókori gyökerekre visszanyúló, középkoron is átívelő felfogást foglalja össze Thomas Keating, amikor jellemzi a kontemplációhoz való viszonyulás történetét könyvében (lásd KEATING 2006, pp. 31-50); többek között így fogalmaz: „A világ vallásainak szellemi hagyományaiban, úgy Keleten, mint Nyugaton, megfigyelhetö az a tendencia, hogy elszigeteljék a keresöt, speciális helyre különitsék, és megkülönböztessék azoktól az emberektöl, akik családi, szakmai vagy üzleti életet élnek a világban... Ami a keresztény hagyományt illeti, Órigenész, az alexandriai teológiai iskola negyedik századi képviselöje úgy vélte, hogy a világban élö keresztény közösség az aszkézis megfelelö helyszine. Csak Antal példája és Atanáz erröl szóló beszámolója hatására vált a 
élet lényegére világít rá, amikor kimondja a hívő életmód alapelemeivel (szeretetparancs szerinti élet, bünbánat, szentségek gyakorlata) kapcsolatban, hogy ez az Istennel való egyesülés megélése. Gondolata egybevág a Lumen gentium, az Egyházról szóló zsinati konstitúció szemléletével (1964). Elég ehhez az ötödik fejezetet felidéznünk, ahol az életszentségre szóló egyetemes meghívásról van szó az Egyházban (LG 39-42), vagy elolvashatjuk a szöveg egész gondolatmenetének rögtön a kiindulópontját, mely szerint „az Egyház Krisztusban mintegy szentsége, azaz jele és eszköze az Istennel való bensöséges egyesülésnek” (LG 1). Ennek a bensőséges egyesülésnek a megragadása ez a megfogalmazás is:

„A Lélek az Egyházban és a hívők szivében mint templomban lakik.” (LG 4)

Az Istennel való egység gondolatán belül, Szent Ferencnek a hívőkhöz írt levelében megjelenik a szentháromságos kapcsolat témája, amely a folytatásban még inkább kifejtést nyer, és amelynek hangsúlyos eleme a hívő lélek és Jézus Anyja, Mária párhuzamba állítása:

\title{
„Jegyesei vagyunk (ti. Jézus Krisztusnak), amikor a Szentlélek által a mi Urunk Jézus Krisztussal egyesül a hivö lélek; testvérei vagyunk, amikor megtesszük az Atya akaratát, aki a mennyben van; anyja vagyunk, amikor szivünkben és testünkben hordozzuk öt az isteni szeretet s a tiszta és öszinte lelkiismeret által, és szent munkálkodással, melynek példaként kell mások elött világítania, világra szüljük öt." (1LHív 8-10) ${ }^{17}$
}

Amint a Szüz Anya szíve alatt hordozta a testté lett Igét, a hívő ember is önmagában hordozza szívében és testében - a Fiút, és amint Mária világra szülte őt, a hívő ember is mintegy lelkileg világra hozza, amikor keresztényként él. Ennek szemlélésében Ferenc egészen hasonlónak látja a hívő embert és Máriát. Ennek köszönhető, hogy egyrészt az anyaság metaforáját alkalmazza a hívőre, másrészt az Egyház (Ecclesia) metaforáját alkalmazza Máriára. A Boldogságos Szüz üdvözlése címü meditatív imában Ferenc - a patrisztikus hagyományban szintén jelenlévő - kifejezésekkel szólítja meg az Istenszülőt:

\author{
„Üdvözlégy [...] Mária, \\ ki szüz lévén templommá lettél [...] \\ Üdvözlégy, az ö palotája, \\ üdvözlégy, az ö sátra, \\ üdvözlégy, az ö háza."
}

Az eredeti szövegben a templom szó helyén Ecclesia, vagyis Egyház áll, amely a latinban egyszerre vonatkozhat az épületre, valamint a tanítványi közösségre. Az Eucharisztia-hit így kerül összefüggésbe a Mária-tisztelettel, illetve a kettő így erősíti egymást. Mária a hívő ember és egyszersmind a hívő közösség tökéletes képévé válik, a hívő ember és a hívő közösség pedig az Urat hordozza magában és felmutatja a világnak. ${ }^{18}$

Egy másik érdekessége a Levél a hivőkkhöz idézetének a „szent munkálkodás” kifejezés, amely Ferencnek visszatérő szófordulata (vö. 1LHív 1,10; 2,21; 2LHív 53; Végr 39). Annak a misztikus egységnek a kifejezése ez, amely létrejöhet a szentháromságos Isten és a hívő ember között. Nem is mindig világos, illetve nem is lehet teljes biztonsággal szétválasztani, hogy a kifejezés egyes előfordulásakor kinek a munkálkodásáról van szó: a hívő emberéről vagy a Szentlélekéről. A sancta

kereszténységben a világ elhagyásának gyakorlata az isteni egyesüléshez vezetö mérvadó úttá. Antalnak nem állt szándékában ezt kizárólagos úttá tenni”" (KeATING 2006, pp. 45-46).

17 A hosszabb változatban: 2LHív 51-53.

18 Szüz Mária mint az Egyház elöképe szintén megjelenik - a patrisztikus tanítást idézö - Lumen gentium szövegében (vö. LG 63-64). „Az Egyház, miközben Mária titokzatos szentségét szemléli, szeretetét utánozza és hüségesen teljesíti az Atya akaratát, Isten igéjének hivö elfogadása által maga is anya lesz” (LG 64). 
operatio egyszerre idézi és feltételezi a híveiben szüntelenül munkálkodó Istent és a szent cselekvéssel a világban tanúságot tevő hívőt.

A Levél a hivőkhöz második, hosszabb - és valószínűleg későbbi - változata több eucharisztikus utalást is tartalmaz még a fenti - misztikus egység - témán kívül, amelyek egybevágnak a korábban már említett gondolatokkal: karácsony és húsvét együttszemlélése az Eucharisztia titkával (lásd Az Atya Igéje c. rész: 4-15); áldozás (14-15), gyónás és áldozás (22-27), klerikusok tisztelete és az Eucharisztia (33-35). Ahogy Ferenc a saját útján megtapasztalta a hit ajándékát a templomokban, a papi szolgálaton keresztül megjelenő Eucharisztiában, úgy mindenki számára ezt kínálja fel járható útként. A Levél a hivőkhöz ezen a ponton egybevág a Végrendelet visszatekintéseivel:

„És az Úr olyan hitet adott nekem a templomokban [...].

Azután az Úr, egyházi rendjük miatt, akkora hitet adott és ad nekem papjaiban, akik a római Szentegyház szabályai szerint élnek, hogy még ha üldöznének engem, akkor is csak hozzájuk akarok menekülni [...]. És félni, szeretni és becsülni akarom öket és mind a többieket, mint uraimat, és nem akarom vizsgálgatni bennük a bünt, mivel Isten Fiát szemlélem bennük, s uraim ők. És ezt azért teszem, mert Isten legfölségesebb Fiából ezen a világon testileg semmi mást nem látok, mint legszentebb testét és legszentebb vérét." (Végr 4-11)

„Továbbá gyakran be kell térnünk a templomokba, és kötelességünk tisztelni és becsülni a klerikusokat, még ha bünösök is, nem annyira önmagukért, mint inkább hivatalukért és Krisztus legszentebb testének és vérének szolgálatáért."

(2LHív 33)

\section{Kampány az Eucharisztia-tisztelet érdekében}

A fent idézett hosszabb írásokban is megjelenik az a megkülönböztetett figyelem, amelyre Ferenc törekszik minden olyan személy vagy dolog irányában, aki vagy ami az eucharisztikus jelenléthez kapcsolódik: templomok, liturgikus eszközök, az Eucharisztia őrzési helye, az átváltoztatás szavait tartalmazó táblácskák, továbbá papok, egyházi személyek, teológusok. E figyelem mellett jellemző a liturgia megfelelő végzésére, valamint az eucharisztikusan jelen levő Úr imádására, dicséretére való buzdítás is. Mindez tömören, a praktikumot célozva és egyszerü megfogalmazással jelenik meg a rövidebb levelekben is, amelyekkel mintegy kampányt indít Ferenc az Eucharisztia-tisztelet érdekében:

Levél a klerikusokhoz

Levél az őrökhöz I.

Levél a népek vezetöihez

Levél az őrökhöz II. (Ez valójában az előző kettőt propagáló kísérőlevél.)

E levelek közös vonása, hogy szinte kizárólag ugyanaz jelenik meg tartalmukban, és megírásuk motivációja is ugyanaz: kampány „, a mi Urunk Jézus Krisztus legszentebb teste és vére, szentséges nevei és irott igéi" érdekében. E fö témához kapcsolódik a nyilvános istendicséretre való felhívás, valamint a világi hatalmasságoknak írt levélben a megtérésre és a világi hatalommal járó felelősségre való emlékeztetés (LNVez). A történészek mindegyik írást 1220-ra datálják, és Ferenc keleti utazásának tapasztalatát, valamint a már említett Sane cum olim pápai levelet említik, mint amelyek az írások történeti elözményéül szolgáltak (vö. FRANCESCO, D’ASSISI 2009, pp. XIV. és 132, 136, 144; VAIANI, 2015, p. 465).

Ferencnek több sikertelen próbálkozása is volt 1219 előtt arra, hogy eljusson a Szentföldre, és törekvésének legfőbb mozgatórugója a vértanúság utáni vágya volt. Végül 1219 júniusában hajóra száll Kelet felé, és eljut Damiettába, ahol békés körülmények között találkozik az egyiptomi szultánnal (lásd 
VAIANI 2015, pp. 175-200; FRANCESCO, D’ASSISI 2009, pp. XIII-XIV). ${ }^{19}$ Az iszlám világ majd egyéves tapasztalata, a Melek al-Kámil szultánnal való találkozás - az V. keresztes hadjárat idején - mély nyomot hagyott benne. Ennek lenyomatát örzi minden bizonnyal a Meg nem erösitett regula 16. fejezete is, amely azokról a testvérekről szól, ,, akik szaracénok vagy más hitetlenek közé mennek”. Az itt ajánlott békés magatartás és alázatos jelenlét nemcsak az Evangélium szerinti életből következett, hanem a józan ítélőképesség is ezt diktálta. Az igehirdetés megfelelő módjának, idejének és helyének megtalálása „létfontosságú alapelv volt” a misszionárius testvérek számára, hisz könnyen vértanúkká válhattak, ahogy ez öt kisebb testvérrel Marokkóban megtörtént (vö. CSIK 2019, p. 159). Mindemellett a muszlim vallásosság látványa Ferenc Eucharisztia-tiszteletét is formálta. Amikor a népek vezetőihez intézett levelében arra buzdít, hogy mozdítsák elö az Isten tiszteletét, nagy valószínüség szerint a müezzin imára hívásának gyakorlatának megtapasztalása áll a háttérben:

„És a rátok bizott nép körében oly nagy tiszteletet ébresszetek az Úr iránt, hogy esténként hirvivö útján vagy más módon adott jelre az egész nép dicsérje a mindenható Úristent, és adjon hálát neki." (LNVez 7)

Hasonló felszólítással találkozunk a Levél az őrökhöz 1. változatában:

„És úgy hirdessétek és prédikáljátok az ő dicséretét minden nemzetnek, hogy minden órában és minden harangszóra az egész nép dicsérje a mindenható Istent, és adjon hálát neki az egész földkerekségen." (1LÖr 8)

E „kampánylevelekben” a következőkkel kapcsolatban olvashatjuk Ferenc felhívását:

1. Megkülönböztetett figyelem az Úr , legszentebb teste és vére, szentséges nevei és írott igéi” iránt, ,, melyek megszentelik a testet”.

2. A szentmise bemutatásának hívő és szabályos módja.

3. A liturgikus eszközök igényes és drága kivitelezése.

4. Az Eucharisztia őrzési helyének elkülönítése és díszes megkülönböztetése.

5. A prédikációkban tanítás arról, hogy az üdvösség feltétele a bünbánattartás és a szentáldozás.

6. Térdre borulás az Eucharisztia előtt (akár a templomban, akár templomon kívül).

7. A nép közös és nyilvános istendicsérete.

\section{A testvéri kapcsolat mint eucharisztikus valóság. A lábmosás metaforája}

Az eddigieket összefoglalva: Szent Ferenc számára az Eucharisztia-tisztelet magában foglal egy teológiai látásmódot, amelyben együtt szemléli azt a megtestesülés és a megváltás misztériumával, valamint az imádás belső magatartását, amelynek az imádságon túl az Egyház, a papok és a teológusok iránti tiszteletben, továbbá a liturgia eszközeivel kapcsolatos különleges figyelemben külső megnyilvánulása is van. Mindezt az a törekvés teszi teljessé, amely Ferencet jellemzi a testvéri kapcsolatok terén, és amelynek legkifejezőbb metaforája a lábmosás. Ennek egyik előfordulása A Meg nem erösitett regula 6 . fejezetében van (A testvéreknek az elöljárójukhoz való folyamodásról, és hogy egy testvért se hívjanak priornak). A kontextus miatt érdemes az egész - egyébként rövid - fejezetet idézni:

„Ha a testvérek, bármely helyen is vannak, nem tudják életmódunkat megtartani, amilyen gyorsan csak tehetik, folyamodjanak miniszterükhöz, és jelentsék ezt neki. A miniszter pedig olyan igyekezettel gondoskodjék róluk, amint kivánná, hogy hasonló helyzetben róla is gondoskodjanak. És senkit ne hívjanak priornak, hanem mindenkit egyaránt kisebb testvérnek hívjanak. És egyik a másiknak mossa meg lábát."

19 Rendtörténeti monográfiájában Merlo 1212/1213-ra teszi az első kísérletet (vö. MERLO 2003, p. 26). 
$(\mathrm{RnB} 6,1-4)$

Itt a lábmosás képe a kisebb testvérek egymáshoz való viszonyát írja le Ferenc szándéka szerint. Egy központi szimbólum, amely az utolsó vacsorát - vagyis az első eucharisztiát - jeleníti meg, az Úr önátadására utal, és nem utolsósorban a szeretet evangéliumi, új parancsát idézi fel, amelynél nincs nagyobb. A regula szerint minden testvéri kapcsolat mércéje ez, amely bármilyen élethelyzetben érvényes. A fejezet kiindulópontja az a sajátos belső konfliktus, amit egy szerzetes akkor él meg, amikor azt tapasztalja, hogy életének külső folyása teljesen ellentmond annak a hivatásnak, amelyre egykor rátette az életét. A regula útmutatása a belső konfliktussal vívódó testvér és az elöljáró számára egyaránt követelményt állít: az alárendelt testvér forduljon elöljárójához, ez utóbbi pedig gondoskodjon róla. Ehhez mindkettőjük számára az ad alapot, hogy ugyanaz a hivatásuk (vö. ,,mindenkit egyaránt kisebb testvérnek hivjanak”), és bár feladatuk az éppen aktuális pozíciójukból fakadóan eltérö, gyökerükben mégis azonos: a lábmosás, vagyis az alázatnak, az önátadásnak, a jézusi szeretetnek a végsőkig menő és az üdvösség reményét hordozó konkrét megvalósulása.

Szent János evangéliumában nem úgy találjuk meg az utolsó vacsora leírását, miként az Újszövetség többi párhuzamos helyén. Az eucharisztia elbeszélésének helyén - ti. hogy Jézus kezébe vette a kenyeret és a kelyhet, és „szent igék” kíséretében tanítványainak adta, meghagyva, hogy ezt cselekedjék a későbbiekben az ő emlékezetére - a lábmosás szerepel. ${ }^{20} \mathrm{~A}$ lábmosás képe által a testvéri közösség és a testvéri kapcsolatok kerülnek eucharisztikus megvilágításba. Még egyszerübben szólva, e szemléletmód szerint a testvéri közösség és a testvéri kapcsolat maga eucharisztia, a feltámadt Úr jelenlétét hordozó evilági valóság. Ahogy a kenyér és a bor színébe tudja zárni önmagát értünk a megölt és élő Bárány, úgy a testvéri közösség „,színe” alatt is rejtőzhet. A testvéri közösség nemcsak azért eucharisztikus közösség, mert tagjai hívők, illetve járnak misére, és az egy kenyérből élnek, hanem pusztán már azért is, mert kisebb testvérként egymás lábát mosva, vagyis a szeretet végső tetteit gyakorolva egymás iránt a feltámadt Úrral egyesülnek, és Öt jelenítik meg.

A szolgáló szeretetnek ezt a krisztushordozó, Krisztust megjelenítő valóságát tanítja a negyedik intelem is:

„, 'Nem azért jöttem, hogy nekem szolgáljanak, hanem hogy én szolgáljak', mondja az Úr. Azok, akik mások fölé vannak rendelve, csak úgy dicsekedjenek elöljáróságukkal, mintha kizárólag a testvérek lábának megmosásának feladatát bizták volna rájuk. És ha elöljáróságuk elvétele jobban megzavarja öket, mint a lábmosás feladatának elvonása, annál inkább csak a maguk erszényébe gyüjtögetnek lelkük veszedelmére."

(Int 4)

E meggyőződés felől visszatekintve Ferenc megtérésére már a leprásokkal való találkozás is, mint eucharisztikus valóság szemlélhető: ,,irgalmasságot cselekedtem velük” - írja Ferenc (Végr 2).

„És amikor eltávoztam tölük, az, ami nekem keserünek tünt, átváltozott számomra a test és a lélek édességévé." (Végr 3)

Hasonlóképp a testvérek elfogadása, mint akiket ,az Úr adott” (Végr 14), és a testvéri közösségben való minden áron való kitartás - amint ez Az igazi és tökéletes örömröl szóló tanításban elénk tárul szintén úgy válik érthetővé és élhetővé, ha megalapozza az a hit, hogy ez a közösség a feltámadt Úr jelenlétét hordozza, miként a kenyér és a bor egyszerü hétköznapi valósága. 


\section{IV. Összegzés}

Amikor Assisi Szent Ferenc hitét írásain keresztül közelítjük meg, az az Eucharisztia-tisztelet következő elemeit látjuk:

1. Az imádás és szemlélés mint az istenkapcsolatban élő hívő ember belső magatartása.

2. Isten alázatának szemlélése az Eucharisztia misztériumában és együttlátása a megtestesülés és a megváltás titkával.

3. A szentmise mint a hívő élet középpontja; gondosság a liturgiában.

4. Az Istennel való misztikus egység megélése a hívő és szentségi élet (gyónás, áldozás) által.

5. Tanúságtétel az eucharisztikusan jelen levő Úrról a hitüktől elidegenedett „keresztények” körében.

6. A kisebb testvéri alázat mint eucharisztikus életforma, a testvéri kapcsolat mint éltető eucharisztia.

További gondolkodás tárgya lehet, hogy miként jelennek meg ezek az elemek az egyes életrajzokban és legendákban, illetve hogyan újultak meg a későbbi korok ferences hagyományában, a szentté lett kisebb testvérek életében. Befejezésül idézzük fel a rendalapító kultuszát erősítő egyik csodaelbeszélést, amelyet Celanói Tamás nyomán Szent Bonaventura is megörökített (CÉCs 118; LMCs 7,2). A történet szerint egy vak asszony Szent Ferenc ünnepén a szentmise közben éppen „Krisztus testének felemelésekor” visszanyeri a szeme világát. Bonaventura így kommentálja az eseményt:

„Bizony ujjongott az asszony nemcsak azért, mert visszanyerte testi szeme fényét, hanem azért is, mert kiérdemelte, hogy boldog Ferenc érdemei folytán és a hit erejével támogatva elöször ama csodálatos Szentséget szemlélje, amely a lélek igazi és élö világossága."

\section{Irodalom - References}

AUGUSTINUS: Sermo 57 (PL 38,386-393).

BRUnetTe, P. (2016): Le Ammonizioni di san Francesco. Parole che aiutano a vivere (Presenza di San Francesco 59.). Edizioni Biblioteca Francescana, Milano.

CAROLI, E (a cura di) (2004): Fonti francescane. Nuova edizione, Editrici Francescane, Padova.

Chrysologus, P.: Sermo 67 (PL 52,390-393).

CONCILIUM LATERANENSE, IV (1215): Constitutiones Concilii Lateranensis. [online] [2019. június] http://www.documentacatholicaomnia.eu/03d/1215-

1215,_Concilium_Lateranense_IIII,_Documenta,_LT.pdf

CsIK, T. (2019): Assisi Szent Ferenc és Melek al-Kámil szultán találkozója 1219-ben. Egy 800 évvel ezelőtti esemény történelmi háttere és a „vallásközi dialógus” lehetősége az V. keresztes hadjárat éveiben. Acta Pintériana, 5: 143-166. doi:10.29285/actapinteriana.2019.5.143

CyPRIANUS: De Oratione Dominica (PL 4,519-542).

FERENC, ASSISI SZENT (2018): Assisi Szent Ferenc irásai (Ferences Források Magyarul 3.). Magyarok Nagyasszonya Ferences Rendtartomány, Budapest.

FERENC, ASSISI SZENT (1997): Assisi Szent Ferenc perugiai legendája (Ferences Források 5.). Agapé, Szeged. [PL]

FILA, B. \& JUG L. (összeáll. és ford.) (1997): Az egyházi tanitóhivatal megnyilatkozásai. Örökmécs Alapítvány, Kisterenye - Budapest. 
FRANCESCO, D’ASSISI (2009): Scritti. Frati editori di Quaracchi, Fondazione Collegio S. Bonaventura, Grottaferrata. (ed. critica a cura di C. PAOLAZZI OFM)

FRANCESCO, D'ASSISI (2012): La Regola di frate Francesco. Eredità e sfida. Editrici Francescane, Padova. (a cura di P. MARANESI \& F. ACCROCCA)

INNOCENTIUS, III: Mysteriorum Evangelicae Legis Et Sacramenti Eucharistiae. Libri Sex (PL 217,763915). [online] http://www.documentacatholicaomnia.eu/01p/1198-1216,_SS_Innocentius_ III,_Legis_et_Sacramentis_Eucharistiae_Libri_Sex,_MLT.pdf

Jungmann, J. A. (1977): A szentmise. Prugg Verlag, Eisenstadt. (ford. Sántha M.)

KeAting, T. (2006): Nyitott tudat, nyitott szív. Az evangélium kontemplatív dimenziója. Filosz, Budapest. (ford. Malik Tóth I.)

KovÁCs, E. (2007): Koncelebráció: az egység jele vagy a kényszerítés eszköze? Miles Christi, 9(1): $38-55$.

MCPARTLAN, P. (2015): Az üdvösség szentsége. Bevezetés az eucharisztikus egyháztanba (Sensus Fidei Fidelium 5.). L’Harmattan Kiadó \& Sapientia Szerzetesi Hittudományi Főiskola, Budapest. (ford. Mészáros V.)

MerLo, G. G. (2003): Nel nome di san Francesco. Editrici Francescane, Padova.

PIERRARD, P. (1994): A katolikus egyház története. Agapé, Budapest. (ford. Hámori Gy.)

Sacrorum conciliorum nova et amplissima collectio (1778). vol. 22., Venezia, p. 754 CD. Idézi: P. MARANESI (2009): L'eredità di frate Francesco. Lettura storico-critica del Testamento. Edizioni Porziuncola, Assisi, p. 178.

VAIAnI, C. (2013): Assisi Szent Ferenc útja (Kis Út 8.). L’Harmattan Kiadó \& Sapientia Szerzetesi Hittudományi Főiskola, Budapest. (ford. Dankó L.)

VAIANI, C. (2015): Storia e teologia dell'esperienza spirituale di Francesco d'Assisi (Fonti e Ricerche 23.). Edizioni Biblioteca Francescana, Milano. 